\title{
THE EFFECT OF MODIFICATION OF THE CHAN PASSING GAME ON THE BOTTOM PASSING SKILL OF VOLLEYBALL ( Case Study Quasi Eksperimen In Al-Ihya KAduronyok)
}

\author{
Sukron Ma'mun' ${ }^{1}$ Nurhalim² \\ Sekolah Tinggi Keguruan dan Ilmu Pendidikan Syekh Manshur \\ Jalan Raya Labuan KM 5 Kadulisung Pandeglang \\ Ponsel: 083870130605 \\ Surel: sukronmamun219@gmail.com
}

\begin{abstract}
This Research aim tyo know the effect of chain passing game modification exercise on volleyball bottom passing skills. The study used a quasi-experimental method. Sampling using random sampling. The independent variable of this research, namely, modofication of chain passing, as the dependent variable, namely passing under the population of this study at SMK Al-Ihya Kaduronyok and the sample of this study amounted to 16 people. The results of the study showed that there as an effect of modification of the chain passing gam eon volleyball under passing skills in extracuricular activities at Al-Ihya Kaduronyok Vocation School. This is evidenced by the significance value at Tcount $=6.0797>$ Ttable $=1.687$. The average value of the pretest result was 7.375 while the posttest increased to 18.5. Based on hypothesis testing, $i$ tis stated that there is a positive influence berween the effect of modofying the chain passing gme on vollyball bottom passing skills. A good passing player isable to return the ball wwell ti this friend or can hold the ball by not deviating and just at the times of his passing.
\end{abstract}

Keywords: Modification, chain passing, bottom passing.

\section{PENDAHULUAN/INTRODUCTION}

Permainan bola voli adalah suatu permainan cepat. Artinya waktu dalam setiap pertandingan sangat terbatas, yaitu hingga 25 poin. Permainan bola voli di awali dengan pukulan service yang merupakan pukulan awalan dalam membangun serangan pada pertahanan lawan.

Seiring berkembangnya jaman, permainan bola voli menjadi salah satu cabang olahraga prestasi di Indonesia. Permainan bola voli dapat dimainkan oleh anak-anak hingga orang dewasa, baik wanita maupun pria. Permainan bola voli dapat di gunakan sebagai sarana pembentukan individu, baik perkembangan jasmani maupun rohani.

Dalam suatu latihan khususnya dalam ekstra kurikuler penjaskes di sekolah, bisa dilakukan dengan menggunakan modifikasi. Modifikasi merupakan salah satu usaha yang dapat dilakukan oleh para pelatih agar ekstra kurikuler mencerminkan develop mentaly, appropriate, practice, artinya bahwa tugas latihan yang diberikan harus memperhatikan perubahan kemampuan pemain dan dapat membantu mendorong perubahan 
tersebut. Oleh karena itu, tugas latihan tersebut harus sesuai dengan tingkat perkembangan pemain yang sedang berlatih. Tugas latihan yang sesuai ini harus mampu mengakomodasi setiap perubahan dan karakteristik setiap individu serta mendorong perubahan kearah yang lebih baik.

Permainan bola voli memiliki beberapa bentuk teknik dasar yang perlu dikuasai oleh seorang pemain. Untuk meningkatkan keterampilan, teknik permainan bola voli harus dilatih dan dievaluasi agar pelatih atau guru mengetahui kelemahan dan kekurangan teknik tersebut. Salah satu teknik yang harus dikuasai pemain bola voli yaitu teknik passing bawah. Passing bawah merupakan suatu teknik dasar di dalam permainan bola voli. Teknik passing bawah adalah teknik mengoper bola kepada teman satu tim. Passing merupakan langkah awal penyusunan serangan kepada lawan. Passing bawah dilakukan untuk mengoper bola tinggi yang dapat digunakan untuk teknik mengumpan.

Pelatihan ini merupakan pelatihan yang bisa dilakukan dengan individu, berpasangan, ataupun dengan bantuan benda di sekitarnya. Teknik dasar passing bawah adalah pengoperan bola kepada temannya sendiri dalam suatu regu dengan suatu teknik tertentu, sebagai langkah awal pola menyusun serangan kepada regu lawan. Passing dapat dilakuakn dengan dua cara, namun tetapi yang akan saya contohkan adalah passing bawah.

Gerakan lanjutan, setelah ayunan lengan mengenai bola, kaki belakang melangkah ke depan untuk mengambil siap kembali. Ayunan lengan untuk passing bawah ke depan tidak melebihi sudut $90^{\circ}$ dengan bahu atau badan. Oleh karena itu pemain SMK Al-Ihya Kaduronyok harus berlatih dengan baik, karena masih banyak kekurangan dalam melakukan passing bawah dengan benar yaitu: (1) ketepatan passing bawah pada siswa masih kurang. (2) kurangnya driil pada teknik passing bawah. (3) kurangnya memahami konsep latihan.

Oleh karena itu, perlu diterapkan metode latihan yang tepat untuk meningkatkan passing bawah bola voli. Metode latihan yang akan diterapkan dalam penelitian ini yaitu latihan passing berantai. Melalui latihan tersebut diharapkan teknik passing bawah pemain lebih baik. Dari latar belakang di atas pengaruh "modifikasi permainan pasing berantai terhadap keterampilan passing bawah bola voli pemain SMK Al-Ihya Kaduronyok Tahun Pelajaran".

Berdasarkan masalah di atas, peneliti hanya membatasi pada masalah 
yang akan diteliti agar ruang lingkup peneliti ini tidak terlalu luas, sehingga dapat lebih terarah pada tujuan, maka peneliti menganggap perlu untuk memberikan pembatasan pada aspekaspek yang akan diteliti, yaitu:

a. Variabel bebas (X): modifikasi permainan

b. Variabel terikat (Y): Keterampilan teknik dasar passing bawah bola voli.

\section{KAJIAN TEORETIK/THEORETICAL REVIEW}

Bolavoli adalah permainan yang terdiri atas dua regu yang beranggotakan enam pemain, dengan diawali memukul bola untuk dilewatkan di atas net agar mendapatkan angka, namun tiap regu dapat memainkan tiga sentuhan untuk mengembalikan bola. Permainan dilakukan di atas lapangan berbentuk persegi empat dengan ukuran $9 \mathrm{~m} \times 18 \mathrm{~m}$ dan dengan bentangan net di tengah-tengah lapangan.

(Suardi. 2019: 94). Tujuan dari permainan ini adalah untuk menjatuhkan bola di daerah lawan. Setiap tim dapat melakukan tiga pantulan untuk mengembalikan bola (di luar perkenaan blok). Bola dinyatakan dalam permainan setelah bola dipukul oleh pelaku servis melewati atas net ke daerah lawan. Permainan dilanjutkan hingga bola menyentuh lantai, bola "keluar", atau satu tim gagal mengembalikan bola secara sempurna.

Permainan bola voli dimainkan 2 tim di dalam lapangan yang berukuran panjang 18 meter, sedangkan lebarnya 9 meter. Setiap tim terdiri dari 10 pemain meliputi 6 pemain inti dan 4 pemain cadangan. Apabila dilapangan terdapat kurang dari 6 pemain, maka tim yang bersangkutan akan dianggap kalah (Rohendi, 2017: 14).

Bola voli merupakan suatu
permainan yang dimainkan dalam
bentuk team work atau kerjasama tim, dimana daerah masing-masing tim dibatasi oleh net.

Tujuan utama dari setiap tim adalah memukul bola ke arah bidang musuh sedemikian rupa sehingga lawan tidak dapat mengembalikan bola. Berdasarkan pendapat ahli di atas, dapat ditarik kesimpulan bahwa bola voli adalah permainan yang terdiri atas dua regu yang beranggotakan enam pemain, dengan diawali memukul bola untuk dilewatkan di atas net agar mendapatkan angka, namun tiap regu dapat memainkan tiga pantulan untuk mengembalikan bola. Permainan dilakukan di atas lapangan berbentuk persegi empat dengan ukuran $9 \times 18 \mathrm{~m}$ dan dengan ketinggian net 2,24 m untuk 
putri dan 2,43 m untuk putra yang memisahkan kedua bidang lapangan.

Fasilitas dan perlengkapan bola voli merupakan segala hal berbentuk barang yang berguna untuk memperlancar proses latihan atau pertandingan bola voli. Fasilitas dan perlengkapan bola voli terdiri atas lapangan, jaring, bola, dan perlengkapan pemain. Fasilitas bola voli terdiri dari: (1) lapangan permainan bola voli, (2) net atau jaring, (3) tiang dan tongkat, dan (4) bola voli. Berikut ini penjabaran terkait fasilitas permainan bola voli:

Teknik passing dilakukan untuk mengendalikan permainan. Pemain dapat melakukan passing untuk menerima bola, menangkis, sekaligus mengembalikan serangan lawan. Passing juga berguna untuk mengoper bola atau memberikan umpan kepada rekan satu tim.

Teknik ini biasanya dilakukan untuk memberikan umpan kepada rekan setim yang akan melakukan smash. Passing bawah dilakukan dengan kedua tangan. Bola diterima dengan kedua Pergelangan tangan di rapatkan lalu melambungkannya lagi ke atas atau ke arah yang diinginkan. (Azhar, 2013: 20)

Pada dasarnya passing bawah adalah bola di voli ke atas, dan mengoperkan bola ke pada teman sendiri dalam satu regu denagn suatu teknik passing bawah, sebagai langkah awal untuk menyusun pola serangan kepada regu lawan.

Adapun sikap permulaan itu adalah sebagai berikut: badan berdiri tegak dengan salah satu kaki berada di depan kaki yang lain. Dianjurkan bila tidak kidal kaki kiri lebih berada ke depan kaki kanan, lutut ditekuk, badan agak condong ke depan dengan tangan siap berada di depan dada. Tahapan dalam melakukan teknik passing bawah dalam permainan bola voli dibagi menjadi persiapan, persentuhan atau perkenaan, dan sikap akhir. Persiapan dalam melakukan teknik passing bawah adalah dengan mengambil sikap normal, mengambil tumpuan kaki selebar bahu, kemudian tangan siap di depan badan.

Latihan teknik (technique training) adalah latihan untuk meningkatkan kualitas teknik-teknik gerakan yang diperlukan dalam cabang olahraga tertentu yang dilakukan oleh atlet. Latihan teknik merupakan latihan yang khusus dimaksudkan guna membentuk dan mengembangkan kebiasaankebiasaan motorik atau perkembangan neuromuscular pada suatu gerak cabang olahraga tertentu. Kesempurnaan teknik-teknik dasar dari setiap gerakan akan menentukan gerak 
keseluruhan. Oleh karena itu, gerakgerak dasar setiap bentuk teknik yang diperlukan dalam setiap cabang olahraga haruslah dilatih dan dikuasai secara sempurna.

METODE PENELITIAN/RESEARCH METHOD

Dalam suatu penelitian pasti mutlak diperlukan metode yang akan digunakan. Karena dengan menggunakan metode maka terdapat cara untuk menyelesaikan sebuah penelitian. Artinya melalui penggunaan metode serta pemilihan sebuah metode yang tepat maka akan membantu jalannya sebuah penelitian. Penelitian ini dilakukan dengan cara metode eksperimen.

Metode eksperimen adalah kegiatan yang terinci yang di rencankan untuk menghasilkan data untuk menjawab suatu masalah atau menguji sesuatu hipotesis. Sugiono (2015:89) Suatu eksperimen akan berhasil jika variabel yang dimanipulasi dan jenis respons yang diharapkan dinyatakan secara jelas dalam suatu hipotesis, juga kondisi-kondisi yang akan dikontrol sudah tepat. Jadi metode eksperimen ini digunakan untuk mengungkap ada atau tidaknya pengaruh dari variabel-variabel yang telah dipilih untuk dijadikan penelitian.
Berdasarkan uraian diatas, maka peneliti dapat menarik kesimpulan, bahwa metode eksperimen Jadi adalah cara penyajian pelajaran dengan suatu percobaan, mengalami dan membuktikan sendiri apa yang dipelajari, serta siswa dapat menarik kesimpulan dari proses yang dialaminya. Adapun alasan penulis menggunakan metode penelitian eksperimen karena dalam penelitian ini penulis bertujuan untuk mengetahui sejauh mana berhasil atau tidaknya penerapan latihan modifikasi permainan terhadap keterampilan pasing bawah bola voli.

HASIL

DAN

PEMBAHASAN/RESULT

AND DISCUSSION

Dalam penelitian ini data yang diperoleh melalui tes awal dan tes akhir belum begitu berarti dan masih merupakan skor-skor mentah. Untuk

mendapatkan kesimpulan serta arti dan makna dari data-data tersebut, selanjutnya penulis diolah dengan melakukan pengukuran dan analisis secara statiska. Pengolahan dan analisis data dalam penelitian ini berdasarkan kepada langkah-langkah penelitian yang telah penulis susun sebelumnya. Adapun hasil pengolahan 
data analisis data tersebut penulis permainan passing berantai memiliki uraikan pada tabel-tabel dibawah ini:

Perhitungan Rata-rata dan Simpangan Baku Eksperimen

\begin{tabular}{|c|c|c|c|c|}
\hline Tes & $\begin{array}{c}\text { Jumlah } \\
\text { sampel }\end{array}$ & $\begin{array}{c}\text { Rata- } \\
\text { rata }\end{array}$ & $\begin{array}{c}\text { Simpangan } \\
\text { baku }\end{array}$ & Selisih \\
\hline Pretest & 16 & 7,375 & 1,1474 & \multirow{2}{*}{11,125} \\
\cline { 1 - 3 } Posttest & 16 & 18,5 & 2,92119 & \\
\hline
\end{tabular}

PerhitunganRata-rata dan Simpangan Baku Kelas Kontrol

\begin{tabular}{|c|c|c|c|c|}
\hline Tes & $\begin{array}{c}\text { Jumlah } \\
\text { sampel }\end{array}$ & $\begin{array}{c}\text { Rata- } \\
\text { rata }\end{array}$ & $\begin{array}{c}\text { Simpangan } \\
\text { baku }\end{array}$ & Selisih \\
\hline Pretest & 16 & 7,125 & 1,0878 & \multirow{2}{*}{1.2503} \\
\hline Posttest & 16 & 17 & 2,3381 & \\
\hline
\end{tabular}

Dari tabel diatas, besar nilai ratarata tes awal hasil penerapan modifikasi permainan passing berantai adalah 7,375 dan nilai rata-rata tes akhir 18,5 nilai untuk melihat peningkatan skor dari hasil pretest dan posttest dilakukan dengan cara mengurangi skor posttest dengan skor hasil pretest. Hasil pengurangan antara tes tersebut disebut dengan peningkatan atau disebut juga selisih skor. Selisih skor rata-rata pretest dan posttest adalah 11,125.

Setelah diberikan perlakuan selama 10 kali pertemuan diantaranya tes awal (pretest) dan tes akhir (posttest) dengan lama penelitan terhitung dari 10 Januari sampai dengan tanggal 11 Februari 2021 diperoleh hasil pengujian hipotesis seperti yang tertera diatas. Diketahui bahwa dengan pemberian modifikasi pengaruh yang signifikan dengan variable terikat yaitu terhadap keterampilan pasing bawah bola voli di SMK Al-Ihya Kaduronyok. Berikut hasil pengujian hipotesis yang akan dijabarkan dibawah ini:

Terdapat pengaruh yang signifikan penerapan Modifikasi permainan terhadap keterampilan passing bawah bola voli di SMK Al-Ihya Kaduronyok.

Berdasarkan temuan dari hasil pengujian hipotesis menjelaskan bahwa hasil pengujian menunjukan belajar menggunakan modifikasi permainan memiliki pengaruh yang signifikan terhadap keterampilan passing bawah bola voli siswa ekstrakulikuler SMK AIIhya Kaduronyok dengan menggunakan alat ukur perolehan dari hasil tes awal dan tes ahir passing bawah.

Penerapan modifikasi permainan passing berantai, mempengaruhi keterampilan passing bawah bola voli secara signifikan. Dengan demikian siswa dapat merasakan perubahan keterampilan passing bawah bola voli. Dari penjelasan diatas dapat disimpulkan bahwa dengan diberikan modifikasi permainan dapat meningkatkan keterampilan passing bawah bola voli siswa ekstrakurikurel.

SIMPULAN/CONCLUSION 
Berdasarkan pada pembahasan bab-bab sebelumnya yaitu mulai dari pemaparan latar belakang masalah, rumusan masalah, serta pengajuan hipotesis. Kemudian pada pemahaman kajian teori, penerapan metode penelitian, serta pengolahan data dengan analisis perhitungan statistik, maka dalam penelitian ini penulis menemukan jawaban sebagai akhir dari penelitianyang penulis lakukan.

Selanjutnya beberapa jawaban yang ada, penulis rumuskan dalam bab kesimpulan sebagai akhir dari penelitian yang telah dilakukan. Adapun beberapa kesimpulan penelitian tersebut di antaranya adalah sebagai berikut:

Apakah modifikasi permainan memberikan pengaruh positif untuk proses keterampilan passing bawah dalam permainan bola voli?

Terdapat pengaruh positif terhadap keterampilan passing bawah bola voli dengan prsentasi peningkatan sebesar $16,80 \%$ dengan keterangan rendah.

\section{DAFTAR PUSTAKA/REFERENCES}

Aep Rohendi, (2016.) Pembelajaran

Bola Voli Berbasis

Permaianan. Bandung:

Alfabeta

Azhar , (2013). Pendidikan Jasmani

dan Kesehatan, Jakarta:
Erlangga

Desi. (2013) Pemebelajaran Bola Voli

Berbasis Permainan.

Alfabeta: Bandung

Nurhasan, Nurhasan, (2013) Tes dan

Pengukuran Keolahragaan.

Jurusan Kepelatihan. Fakultas

Pendidikan Olahraga dan

kesehatan. (UPI.BANDUNG 2013).

Richard (1980). Teaching Villy Ball.

America: Moris lundi

Rusmiyadi,I. (2021). Model Latihan

Keterampilan Block Bola Voli

Untuk Siswa Sekolah Menengah

Kejuruan. Jurnal of Sport (Sport

Physical

Education,

Organization, Recreation, and Training).

http:Idoi.org\10.7058\Sport.v5i1.

2987

Suardi, D. (2019;.94 Analisis

Kebugaran Keterampilan Bertan dalam Permainan Bola Voli. Cakraala Pedagogik. http:Ildoi.org\10.51499lcp.v3i2.1 06,

Sugiyono 2016. Metode Penelitian

Kuantitatif, Kualiotatif, dan Kombinasi. Bandung: Alfabet. 